\title{
Congenital Hypothyroidism and Hyperthyroidism in Monozygotic Twin Girls*
}

\author{
PHILIP L. TOWNES and WILLIAM L. BRADFORD
}

\author{
From the Division of Genetics and Department of Pediatrics, University of Rochester School of Medicine and Dentistry, \\ Rochester, New York 14620, USA
}

This report describes monozygous twin girls with different forms of thyroid dysfunction. Twin A was found to have athyreotic hypothyroidism during the first week of life; twin B developed acute hyperthyroidism at 16 years of age. While concordance and discordance for congenital hypothyroidism has been reported in several sets of twins (Table I) there have been no prior reports of congenital hypothyroidism and hyperthyroidism in a single twin pair. Two different forms of thyroid disorder have been reported (Jayson et al, 1967) in only one set of twins: one twin developed hypothyroidism with a Hashimoto's thyroiditis at 29 years of age and her co-twin developed hyperthyroidism at 31 years of age. Although the thyroid disorders in the latter twins occurred in adulthood, the authors suggested a possible biological unity underlying the two forms of thyroid disorder. The present report provides further evidence in support of this possibility.

\section{Case Reports}

The twins were born at St Jerome's Hospital in Batavia, NY on 28 August, 1951 and admitted to Strong Memorial Hospital the following day because of respiratory distress and intermittent cyanosis. They were born to a para 1, gravida 2 married woman after an uncomplicated pregnancy of 7 months duration. She received no medications during the pregnancy. The mother was 27 years of age; the father 30 years of age. The twins have one older brother, one younger brother, and three younger sisters. The parents and sibs are in good health and have no history of thyroid disorder.

Twin $\mathbf{A}$ was a vertex presentation and weighed $1830 \mathrm{~g}$, while twin $\mathrm{B}$ was a footling breech and weighed $1700 \mathrm{~g}$. On admission twin A presented a moderate degree of cyanosis and abdominal distention. A barium enema revealed an atonic colon. Facial features (Fig. 1) were suggestive of hypothyroidism and PBI was found

\footnotetext{
Received 1 October 1970.

* Supported by Grant-in-Aid AM-09247 from the United States Public Health Service.
}

to be less than $1 \mu \mathrm{g} / 100 \mathrm{ml}$. Thyroidal radioactive iodine uptake was reported as 'zero'. On thyroid therapy $(24 \mathrm{mg} / \mathrm{dy})$, the abdominal distention and constipation cleared. Within the next few weeks, the physical features of cretinism disappeared.

Physical and psychomotor development were reasonably good but obviously delayed when compared to twin B (Fig. 2). She walked at 18 months but said no words until 23 months of age. At 26 months she received $90 \mathrm{mg}$ of thyroid extract daily, spoke short sentences, fed herself, and was toilet trained. At 3 years EEG tracings were normal. However, at 12 years of age, twin A's record was abnormal with generalized slowing at rest and during hyperventilation. The voltage was 20 to 50 microvolts in contrast to over 50 microvolts in the case of twin B whose record was reported as normal. At 4 years of age, she received $150 \mathrm{mg}$ of thyroid extract daily. Her IQ was found to be $80-85$ while her sister's IQ was estimated to be 100 .

Between 7 and 9 years of age, thyroid extract was replaced by triiodothyronine, $50 \mu \mathrm{g}$ daily. She has continued to receive triiodothyronine (50-100 $\mu \mathrm{g}$ daily) to the present time. Developmental data are shown in Table II.

Twin B. On admission, twin B had a moderate degree of respiratory distress which promptly subsided and she remained in good condition during the neonatal period. A detachment of her left retina was suspected but never confirmed. At one month of age she weighed $2 \cdot 2 \mathrm{~kg}(4 \mathrm{lb} 13 \mathrm{oz})$.

As indicated in Table II her growth and development has been normal. She remained in good health until age 16 years when she was readmitted with classical symptoms and signs of acute hyperthyroidism. Although previously a superior student her school performance had rapidly deteriorated. She became nervous, excitable, perspired excessively and had a weight loss of $10 \mathrm{lb}$. Her pulse was 140; blood pressure $150 / 80$. She had a prominent thyroid bruit. The PBI was $18 \mu \mathrm{g} \%$; it had been $7 \mu \mathrm{g} \%$ at 12 years of age.

On propylthiouracil ( $75 \mathrm{mg}$ tid) there was immediate improvement. After one year of treatment the medication was discontinued and her PBI was normal $(6.3 \mu \mathrm{g} \%)$.

From Table II it is apparent that both girls maintained height and weight values near the 50 th centile. Twin A 
TABLE I

CONGENITAL HYPOTHYROIDISM IN TWINS

\begin{tabular}{|c|c|c|c|c|}
\hline Author & Case & Zygosity and Sex & Thyroid Status & Comments \\
\hline \multirow[t]{2}{*}{ Dorff (1934) } & 1 & $\mathrm{DZ}: \mathrm{M}, \mathrm{F}$ & $\begin{array}{l}\text { M: hypothyroid } \\
F: \text { normal } \\
\text { Discordant }\end{array}$ & NS \\
\hline & 2 & $\mathrm{DZ}: \mathbf{M}, \mathbf{F}$ & $\begin{array}{l}\text { M: hypothyroid } \\
\text { F: normal } \\
\text { Discordant }\end{array}$ & F: athyreotic \\
\hline \multirow[t]{2}{*}{ Faxen (1935) } & 1 & ? $\mathrm{MZ}: \mathrm{M}, \mathrm{M}$ & $\begin{array}{l}M: \text { hypothyroid } \\
M: \text { normal } \\
\text { Discordant }\end{array}$ & Congenital goiter \\
\hline & 2 & ? $\mathrm{MZ}: \mathrm{F}, \mathrm{F}$ & $\begin{array}{l}\text { F: hypothyroid } \\
\text { F: normal } \\
\text { Discordant }\end{array}$ & NS \\
\hline \multirow[t]{3}{*}{ Hosen (1940) } & 1 & ? $\mathrm{MZ}: \mathrm{M}, \mathrm{M}$ & $\begin{array}{l}\text { M: hypothyroid } \\
M: \text { normal } \\
\text { Discordant }\end{array}$ & NS \\
\hline & 2 & $\mathrm{DZ}: \mathbf{M}, \mathbf{F}$ & $\begin{array}{l}\text { M: hypothyroid } \\
\text { F: normal } \\
\text { Discordant }\end{array}$ & NS \\
\hline & 3 & ? DZ: F, + ? & $\begin{array}{l}\text { F: hypothyroid } \\
\text { Normal (sex not stated) } \\
\text { Discordant }\end{array}$ & NS \\
\hline Grebe (1952) & 1 & ? MZ: M, M & $\begin{array}{l}\text { M: 'thyroid dwarf' } \\
\text { M: normal } \\
\text { Discordant }\end{array}$ & NS \\
\hline Von Harnach (1953) & & $M Z: F, F$ & $\begin{array}{l}\text { F: hypothyroid } \\
\text { F: normal } \\
\text { Discordant }\end{array}$ & $\begin{array}{l}\text { Athyreotic by }{ }^{131} \mathrm{I} \text {; zygosity by blood } \\
\text { groups }\end{array}$ \\
\hline Warkany and Selkirk (1955) & & $\mathbf{M Z}: \mathbf{F}, \mathbf{F}$ & $\begin{array}{l}\text { F: hypothyroid } \\
\text { F: normal } \\
\text { Discordant }\end{array}$ & $\begin{array}{l}\text { 'Not palpable'; zygosity by blood } \\
\text { groups }\end{array}$ \\
\hline $\begin{array}{l}\text { Pickering and Koulischer } \\
(1956)\end{array}$ & & $M Z: F, F$ & $\begin{array}{l}\text { F: hypothyroid } \\
\text { F: normal } \\
\text { Discordant }\end{array}$ & $\begin{array}{l}\text { NS } \\
\text { Zygosity by placenta and blood } \\
\text { groups }\end{array}$ \\
\hline \multirow[t]{2}{*}{ Grieg et al (1966) } & 1 & $M Z: F, F$ & $\begin{array}{l}\text { F: hypotheroid } \\
\text { F: hypothyroid } \\
\text { Concordant }\end{array}$ & $\begin{array}{l}\text { Athyreotic by }{ }^{131} \text { I ; zygosity by } \\
\text { dermatoglyphics and blood types }\end{array}$ \\
\hline & 2 & $M Z: F, F$ & $\begin{array}{l}\text { F: congenital hypothyroid died at age } \\
2 \frac{1}{2} \text { yr } \\
\text { F: developed hypothyroid at age } 4 \text { yr } \\
\text { Concordant }\end{array}$ & $\begin{array}{l}\text { Vestigial thyroid postmortem } \\
\text { Ectopic small thyroid nodule } \\
\text { Zygosity by placenta and blood } \\
\text { groups }\end{array}$ \\
\hline Strickland and Bass (1969) & $\mathbf{I}$ & $M Z: F, F$ & $\begin{array}{l}\text { Both hypothyroid } \\
\text { Concordant }\end{array}$ & Zygosity by blood groups \\
\hline
\end{tabular}

Key: $\mathrm{DZ}=$ unlike sex; ? $\mathrm{MZ}=$ like sex, zygosity not tested; $M Z=$ monozygous by testing; NS = no statement about palpability of thyroid gland.

has had an excellent response to therapy. However her school performance is below that of twin B despite her keen interest and desire to learn. She repeated the 7th grade and at 19 years is now in the 12th grade. Twin B was a good student and completed the 12th grade last year.

Genetic and Zygosity Studies. The occurrence of congenital athyreotic hypothyroidism and thyrotoxicosis in this set of twins prompted further studies of their zygosity. The twins and their parents were extensively typed for blood group antigens, serum proteins, and red cell isoenzymes. Detailed dermatoglyphic analysis was also performed. The results of these studies are shown in Tables III and IV. The twins proved to be identical in all of the typing studies and the dermatoglyphics were also highly indicative of monozygosity. From these studies, the total absolute probability for monozygosity calculated after the method of Smith and Penrose (1955) is 0.99957 or $99.96 \%$.

Blood samples from the twins and their mother were also examined for thyroid antibodies.* All three individuals were found to have negative titres.

A detailed family history was obtained and showed that several members had disorders of thyroid function. The twins' maternal grandmother developed hypothyroidism at age 55 and required thyroid extract daily until her death at age 82. A maternal first cousin, age 37,

* Bio Science Laboratories, Van Nuys, California, USA. 


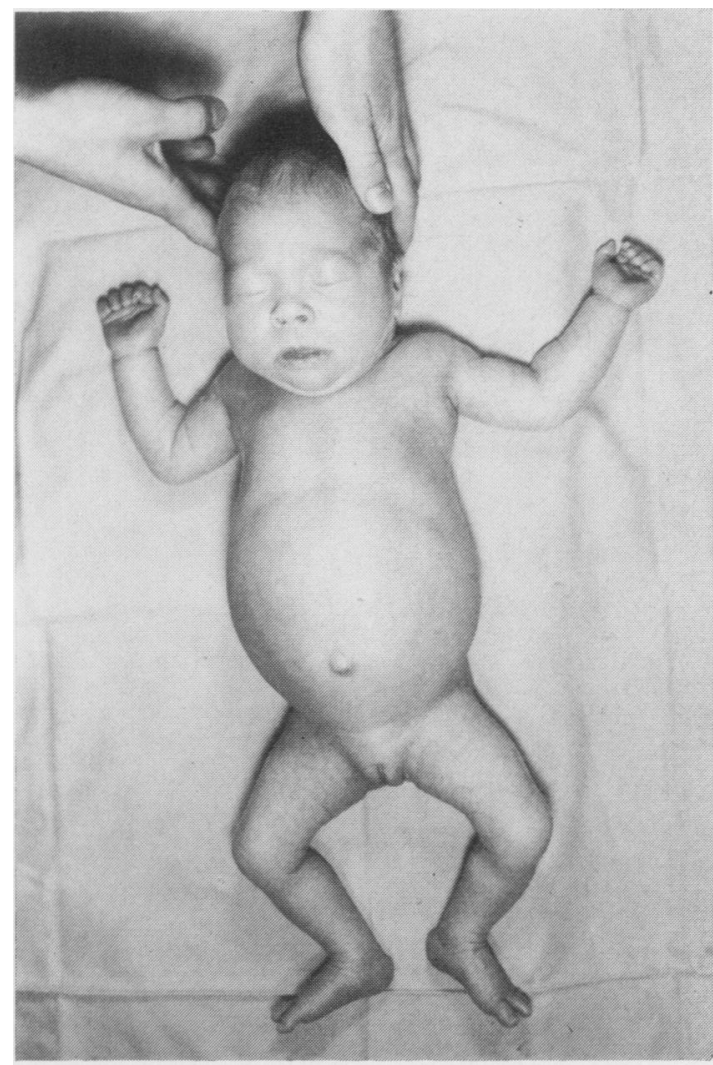

FIG. 1. Twin A at one week of age showing features of cretinism. developed acute thyrotoxicosis two years ago and was hospitalized at this institution for treatment of this disorder. Another maternal first cousin, age 32, also developed hyperthyroidism as a young adult. A maternal first cousin once-removed is mentally retarded and believed to be mildly hypothyroid. In the father's family there are no recognized examples of thyroid dysfunction. These examples of thyroid disease in the maternal family members are suggestive of a genetic predisposition to thyroid disorder.

\section{Discussion}

Twin studies are frequently of value in the assessment of genetic components of disorders. For example, comparison of concordance rates in monozygous and dizygous twins may provide valuable information concerning the relative importance of genetic and environmental factors in the aetiology of a particular disorder. Both concordance and discordance for congenital hypothyroidism have been reported in several sets of twins (Table I). However, these twin studies are of limited value in the assessment of genetic and environmental factors because: (1) relatively few twins have been reported, (2) zygosity has not been determined in all cases, and (3) the abnormality of the thyroid gland was not indicated in several reports (Table I). These uncertainties of zygosity and specific clinical diagnosis in the small number of twins reported preclude valid comparisons of concordance rates in monozygous and dizygous twins.

Despite these limitations, it is of interest to note

TABLE II

DEVELOPMENTAL DATA

\begin{tabular}{|c|c|c|c|c|c|c|}
\hline Twins & Age & Height $(\mathrm{cm})$ & Weight (kg) & Bone Age & PBI $\left(\mu \mathrm{g}^{\circ}{ }_{0}\right)$ & Remarks \\
\hline $\begin{array}{l}\mathbf{A} \\
\mathbf{B}\end{array}$ & Birth & $\begin{array}{l}41 \\
42 \cdot 5\end{array}$ & $\begin{array}{l}1 \cdot 8 \\
1 \cdot 7 \\
\end{array}$ & & 1 & $\begin{array}{l}\text { Hypothyroid head } 27.5 \mathrm{~cm} \\
\text { Head } 26 \mathrm{~cm}\end{array}$ \\
\hline $\begin{array}{l}\text { A } \\
\text { B }\end{array}$ & $1 \mathrm{yr}$ & 二 & $\begin{array}{l}10 \\
10 \cdot 7\end{array}$ & $\begin{array}{l}6-9 \mathrm{mth} \\
6 \mathrm{mth}\end{array}$ & & $\begin{array}{l}2 \text { teeth } \\
5 \text { teeth }\end{array}$ \\
\hline $\begin{array}{l}\mathbf{A} \\
\mathbf{B}\end{array}$ & $2 \mathrm{yr}$ & $\begin{array}{l}82 \cdot 5 \\
87 \cdot 5 \\
\end{array}$ & $\begin{array}{l}13 \cdot 8 \\
14 \cdot 3\end{array}$ & $\begin{array}{l}6-9 \mathrm{mth} \\
15-21 \mathrm{mth}\end{array}$ & & $\begin{array}{l}\text { Head } 47.5 \mathrm{~cm} \\
\text { Head } 47.5 \mathrm{~cm}\end{array}$ \\
\hline $\begin{array}{l}\mathbf{A} \\
\mathbf{B}\end{array}$ & $4 \mathrm{yr}$ & $\begin{array}{l}100 \\
104\end{array}$ & $\begin{array}{l}19 \\
17 \cdot 3\end{array}$ & $\begin{array}{l}3-5 \text { yr } \\
3-5 \text { yr }\end{array}$ & $\begin{array}{l}8 \cdot 7 \\
5 \cdot 4\end{array}$ & $\begin{array}{l}\text { IQ } 80-85 \\
\text { IQ } 100\end{array}$ \\
\hline A & $9 \mathrm{yr}$ & $\begin{array}{l}127 \\
135 \\
\end{array}$ & $\begin{array}{l}28 \cdot 3 \\
28 \cdot 2 \\
\end{array}$ & $\begin{array}{l}6+\mathrm{yr} \\
9 \mathrm{yr}\end{array}$ & & \\
\hline $\begin{array}{l}\mathbf{A} \\
\mathbf{B} \\
\end{array}$ & $12 \mathrm{yr}$ & $\begin{array}{l}150 \\
152 \cdot 5 \\
\end{array}$ & $\begin{array}{l}38 \cdot 6 \\
41 \cdot 8 \\
\end{array}$ & $\begin{array}{l}10 \mathrm{yr} \\
12 \mathrm{yr}\end{array}$ & 7 & \\
\hline $\begin{array}{l}\mathbf{A} \\
\mathbf{B} \\
\end{array}$ & $14 \mathrm{yr}$ & $\begin{array}{l}158 \cdot 7 \\
162 \cdot 5 \\
\end{array}$ & $\begin{array}{l}44 \cdot 5 \\
53 \cdot 2 \\
\end{array}$ & & & Onset menses \\
\hline $\mathbf{A}$ & $16 \mathrm{yr}$ & $\begin{array}{l}165 \\
165 \\
\end{array}$ & $\begin{array}{l}52 \cdot 7 \\
52 \cdot 7 \\
\end{array}$ & $16 \mathrm{yr}$ & $\begin{array}{l}3 \cdot 2 \\
18\end{array}$ & $\begin{array}{l}\text { Onset menses ( } 15 \mathrm{yr} \text { ) } \\
\text { Hyperthyroidism }\end{array}$ \\
\hline $\begin{array}{l}\mathbf{A} \\
\mathbf{B}\end{array}$ & $17 \mathrm{yr}$ & $\begin{array}{l}167 \cdot 5 \\
167 \cdot 5\end{array}$ & $\begin{array}{l}59 \cdot 1 \\
61\end{array}$ & & $\begin{array}{l}3 \cdot 1 \\
6 \cdot 3\end{array}$ & $\begin{array}{l}\text { 10th grade } \\
11 \text { th grade }\end{array}$ \\
\hline
\end{tabular}




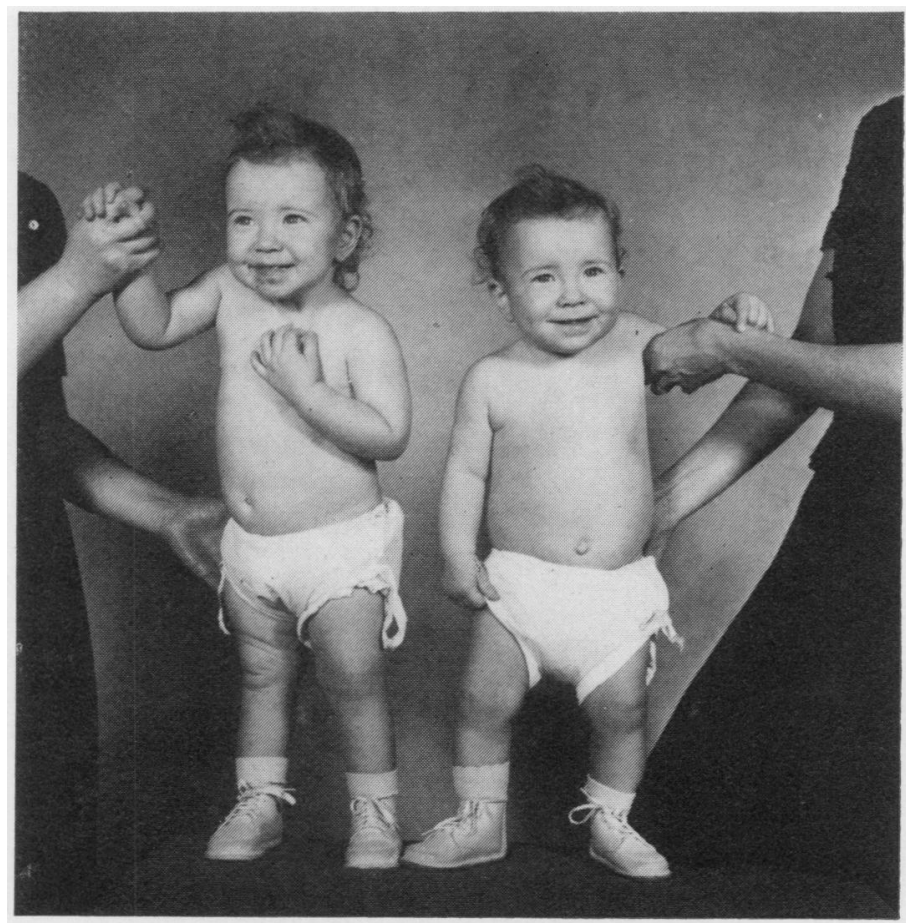

Fig. 2. Twin B (left) and twin A (right) at 12 months of age. Note the facial similarity of twins despite the growth lag of twin A.

(Table I) that all 4 of the unlike-sex (necessarily dizygous) pairs are discordant as are seven of the 10 pairs of like-sex. The 3 pairs who are concordant were shown to be monozygous while monozygosity was established in only 3 of the 7 discordant pairs of like-sex. Therefore, monozygous twins can be either concordant or discordant for congenital hypothyroidism while concordance has not been reported in twins of proven dizygosity.

Similar twin concordance has been observed in hyperthyroidism (Neff, 1932; Bartels, 1941 ; Robinson and Orr, 1955; Cunningham and Kral, 1959; Lowenstein, 1961; McCormack and Sheline, 1961; Hassan et al, 1966), chronic lymphocytic thyroiditis (Irvine et al, 1961; Zaino and Guerra, 1964; Austoni, Callegari, and Borini, 1964; Diamond and Joffe, 1966; Beierwaltes, 1965), and goitrous cretinism (Frierson, Hawk, and Jenkins, 1957), suggesting that these disorders may reflect genetic predisposition. In these examples of twin concordance, the concordance was invariably for the same thyroid disorder. Concordance for two markedly different forms of thyroid disorder has been previously reported in only one twin pair; the adult twins with hypothyroidism and hyperthyroidism reported by Jayson et al (1967) mentioned above. Jayson and his colleagues suggested that 'the finding of these two disorders in identical twins points to a common immunologic defect and a possible genetic factor in their etiology'.

The twins described in this communication provide a second example of monozygous twins with two different forms of thyroid disorder. As in the twins reported by Jayson et al (1967), they may be considered to be concordant if one assumes that the two disorders have a common genetic basis. Conceivably, both twins might have developed hyperthyroidism if thyroid development had not failed in twin A. This developmental failure (athyreosis) may have been merely coincidental (non genetic) or it may have been a varied manifestation of a common genetic defect. Conversely, it is conceivable that the twins were genetically predisposed to athyreosis, and that the defect was not expressed in twin B who subsequently developed hyperthyroidism. The hyperthyroidism in that instance could be coincidental or could represent a varied manifestation of a common genetic defect. Not excluded is the possibility that both thyroid disorders are of non-genetic aetiology. 
TABLE III

TYPING STUDIES

\begin{tabular}{|c|c|c|c|c|}
\hline & Father & Mother & Twin A & Twin B \\
\hline $\begin{array}{l}\text { Anti A } \\
\text { Anti B } \\
\text { Anti AB } \\
\text { Anti D } \\
\text { Anti C } \\
\text { Anti c } \\
\text { Anti E } \\
\text { Anti e } \\
\text { Anti Fy } \\
\text { Anti Jka } \\
\text { Anti Jkb } \\
\text { Anti S } \\
\text { Anti S } \\
\text { Anti M } \\
\text { Anti N } \\
\text { Anti P } \\
\text { Anti Le } \\
\text { Anti Le } \\
\text { Anti Yta } \\
\text { Anti W }{ }^{\mathrm{a}} \\
\text { Anti Kell } \\
\text { Gc } \\
\text { Haptoglobin } \\
\text { Transferrin } \\
\text { Phosphoglucomutase } \\
\text { Acid phosphatase } \\
\text { 6-phosphogluconate dehy- } \\
\text { drogenase } \\
\text { Adenylate kinase } \\
\text { Adenoisine deaminase } \\
\text { Urine pepsinogen }\end{array}$ & $\begin{array}{l}- \\
- \\
+ \\
+ \\
- \\
+ \\
+ \\
+ \\
+ \\
+ \\
+ \\
+ \\
- \\
+ \\
- \\
+ \\
+ \\
- \\
- \\
2-1 \\
2-1 \\
\text { C } \\
1-1 \\
\text { BA } \\
\text { A } \\
1-1 \\
2-1 \\
\text { A }\end{array}$ & $\begin{array}{l}- \\
- \\
+ \\
+ \\
- \\
+ \\
+ \\
+ \\
+ \\
+ \\
+ \\
+ \\
+ \\
+ \\
+ \\
+ \\
+ \\
+ \\
2-1 \\
1-1 \\
\text { C } \\
\text { B } \\
\text { A } \\
1-1 \\
1-1 \\
\text { A }\end{array}$ & $\begin{array}{c}- \\
- \\
+ \\
+ \\
+ \\
- \\
+ \\
+ \\
+ \\
+ \\
+ \\
+ \\
+ \\
+ \\
+ \\
+ \\
+ \\
+ \\
- \\
- \\
1-1 \\
1-1 \\
\text { C } \\
1-1 \\
\text { B } \\
\text { A } \\
1-1 \\
1-1 \\
\text { A }\end{array}$ & $\begin{array}{c}- \\
- \\
+ \\
+ \\
- \\
- \\
+ \\
+ \\
+ \\
+ \\
+ \\
+ \\
+ \\
+ \\
+ \\
+ \\
+ \\
+ \\
- \\
- \\
1-1 \\
1-1 \\
\text { C } \\
1-1 \\
\text { B } \\
\text { A } \\
1-1 \\
1-1 \\
\text { A }\end{array}$ \\
\hline
\end{tabular}

TABLE IV

ESTIMATE OF ZYGOSITY

\begin{tabular}{|c|c|}
\hline Character & $\begin{array}{l}\text { Independent } \\
\text { Relative } \\
\text { Chance } \\
\text { for } \\
\text { Dizygosity* }\end{array}$ \\
\hline $\begin{array}{l}\text { Initial odds } \\
\text { Likeness in sex } \\
\text { Likeness in ABO, Rh, Kidd, Kell, Y } \mathrm{t}^{\mathrm{a}}, \mathrm{Wr}^{\mathrm{a}} \text {, } \\
\text { Transferrin, PGM, AK, 6-PGD } \\
\text { Likeness in MNS } \\
\text { Likeness in Lewis-Secretor } \\
\text { Likeness in P+ } \\
\text { Likeness in Duffy } \\
\text { Likeness in Gc } \\
\text { Likeness in haptoglobin } \\
\text { Likeness in acid phosphatase } \\
\text { Likeness in adenosine deaminase } \\
\text { Likeness in Urine pepsinogen } \\
\text { Difference of total ridge count } \\
\quad(143,153) \\
\text { Difference of } A T D \text { angles }\left(95.0^{\circ},=10\right. \\
\left.97 \cdot 0^{\circ}\right)\end{array}$ & $\begin{array}{l}2.3333 \\
0.5000 \\
1.0000 \\
0.2500 \\
0.5000 \\
0.9034 \\
0.8486 \\
0.2500 \\
0.5000 \\
0.5000 \\
0.5000 \\
0.9394 \\
0.2600 \\
0.4977\end{array}$ \\
\hline
\end{tabular}

Total probability for

dizygosity, $\mathrm{pD}=0.00042467$

$\begin{gathered}\text { Absolute probability for } \\ \text { dizygosity }\end{gathered}=\frac{\mathrm{pD}}{1+\mathrm{pD}}=\frac{0.00042467}{1.00042467}=0.00042449$

$\underset{\text { monozygosity }}{\text { Absolute probability for }}=\frac{1}{1+\mathrm{pD}}=\frac{1}{1.00042467}=0.999576$

* Calculated by the method of Smith and Penrose (1955) with parental data included.

t Non-informative.
There is a large body of data concerning the importance of genetic factors in various thyroid disorders. These have been extensively reviewed by Fraser (1964 and 1969). There are at least 5 autosomal recessive forms of defective thyroxine synthesis in patients with goitrous cretinism. Recessive inheritance has also been well documented in Pendred's syndrome. In non-goitrous (athyreotic, krypto-goitrous) hypothyroidism the genetic components are less well defined. However, Childs and Gardner (1954) reported an increased incidence of thyroid disease in the families of 90 non-goitrous cretins. There have been several reports of parental consanguinity and cretinism in sibs (Koplik, 1897; Osler, 1897; Sill, 1905; Herrman, 1914 and 1917; Bronstein, Bower, and Murphy, 1943; Smeby, 1953; Childs and Gardner, 1954; Nabney, 1954; Ainger and Kelley, 1955; Bernheim et al, 1956; Federman, Robbins and Rall, 1958; Shepard and Gartler, 1960).

From a study of 50 patients, Bernheim (1956) concluded that sporadic cretinism was entirely due to recessive inheritance, however this interpretation has not been supported by other large surveys (Lowrey et al, 1958; Beierwaltes et al, 1959; Andersen, 1961; Carr et al, 1961; Neel et al, 1961. That athyreotic cretinism may be a phenodeviant caused by homozygosis at multiple genetic loci and thus analogous to many congenital malformations has been suggested by Neel et al (1961). In either instance, simple or multifactorial inheritance, concordance would be expected in monozygous twins. The precise mode(s) of inheritance in athyreotic cretinism is therefore poorly understood. Fraser (1964) has estimated that approximately one third of all cases may be due to errors of thyroxine synthesis and presumably of genetic origin.

Autoimmune factors may also be of importance, but their evanescence may result in false negative findings at the time of investigation (Blizzard et al, 1960). While evanescence may account for the negative titres in twins, the negative titre in the mother makes autoimmunization unlikely in this case.

Genetic studies of thyrotoxicosis have been limited and of divergent interpretations, including simple recessive (Bartels, 1941; Martin and Fisher, 1945 and 1951) and dominant inheritance (Climenko 1920; Lewit et al, 1930; Boas and Ober, 1946). However, Fraser (1964) has concluded that although the familial nature is undoubted, the data do not unequivocally indicate single gene inheritance and that thyrotoxicosis may be a 'final pathway of a variety of pathologic processes'.

Of particular interest are reports of families with 
more than one form of thyroid disorder. There have been several reports (Bing, 1932; Bartels, 1941; Gribetz, Talbot, and Crawford, 1954) of families with cases of myxedema and thyrotoxicosis in close relatives, suggesting a possible underlying unity in these disorders (Levitt, 1954). Similarly, a high incidence of thyroid antibodies has been noted (Hall, Owen, and Smart, 1960; Doniach et al, 1961) in relatives of patients with Hashimoto's thyroiditis. Some of these relatives had thyrotoxicosis, myxoedema, Hashimoto's thyroiditis, nodular goitre, or simple thyroid enlargement, while others had normal thyroid function. From these observations, Fraser (1964) has concluded that 'this very wide range of thyroid pathology supports suggestions of the essential biological unity at any rate of proportion of cases of these diseases'. Additional support for this challenging concept is provided in the twins reported by Jayson and colleagues (1967) and by the twins described in this communication.

\section{Summary}

Nineteen-year-old twin girls of proven monozygosity with different forms of thyroid disorders are described. Twin A was found to have athyreotic cretinism at age one week and has responded well to replacement therapy. Twin B developed acute thyrotoxicosis at age 16 years and has responded well to medical management. Monozygosity has been established (absolute probability $99.96 \%$ ) by extensive typing and dermatoglyphic studies. The concurrence of two markedly different forms of thyroid disorders in these monozygous twins suggests a possible common genetic defect or predisposition. Evidence for this interpretation is reviewed and discussed.

We are indebted to Dr Elizabeth B. Robson, University College London and to Dr Lowell R. Weitkamp for performing the isoenzyme typing, and to Dr Gerald Miller and Mrs Jane Corner for the blood-typing studies.

\section{REFERENCES}

Ainger, L. E. and Kelley, V. C. (1955). Familial cretinism: report of 3 cases. Fournal of Clinical Endocrinology and Metabolism, 15, 469-475.

Andersen, H. J. (1961). Studies of hypothyroidism in children. Acta Paediatric. Suppl., 125.

Austoni, M., Callegari, F., and Borini, P. (1964). Tiroidite autoimmune concordante di Hashimoto in gemelli univulari. Folia Allergologica, 11, 78-84.

Bartels, E. D. (1941). Heredity in Graves' Disease. Munksgaard, Copenhagen.

Beierwaltes, W. H. (1965). Thyroiditis. Annals of the New York Academy of Sciences, 124, 586-604.
Beierwaltes, W. H., Carr, E. A., Jr., Raman, G., Spafford, N. R., Aster, R. A., and Lowrey, G. H. (1959). Institutionalized cretins in the State of Michigan. Fournal of the Michigan State Medical Society, 58, 1077-1095.

Bernheim, M., Berger, M., Uzan, R., and Chambron, J. (1956). Les causes du myxoedème congénital et l'aspect génétique des maladies thyroidiennes. Semaine des Hopitaux de Paris, 4104-4113.

Bing, J. (1932). Die genotypisch bedingte sporadische Struma (Kropf) und deren Verhalten zu andern Thyreodea-Leiden. Acta Medica Scandinavica, 79, 298-322.

Blizzard, R. M., Chandler, R. W., Landing, B. H., Pettit, M. D., and West, C. D. (1960). Maternal autoimmunization to thyroid as a probable cause of athyrotic cretinism. New England fournal of Medicine, 263, 327-336.

Boas, N. F. and Ober, W. B. (1946). Hereditary exophthalmic goitre-report of eleven cases in one family. Fournal of Clinical Endocrinology and Metabolism, 6, 575-588.

Bronstein, I. P., Bower, L. E., and Murphy, J. (1943). Familial cretinism. American fournal of Medical Sciences, 205, 114-117.

Carr, E. A., Jr., Beierwaltes, W. H., Neel, J. V., Davidson, R., Lowrey, G. H., Dodson, V. N., and Tanton, J. H. (1961). The various types of thyroid malfunction in cretinism and their relative frequency. Pediatrics, 28, 1-16.

Childs, B. and Gardner, L. I. (1954). Etiologic factors in sporadic cretinism. An analysis of ninety cases. Annals of Human Genetics, 19, 90-96.

Climenko, H. (1920). Heredity in exophthalmic goiter. Archives of Neurology and Psychiatry, 3, 530-535.

Cunningham, J. A. K. and Kral, F. (1959). Thyrotoxicosis in identical twins. New Zealand Medical fournal, 58, 600-603.

Diamond, M. T. and Joffe, B. (1966). Monozygotic twins with chronic lymphocytic thyroiditis (Hashimoto's disease). fournal of the American Medical Association, 198, 182-183.

Doniach, D., Roitt, I. M., Forbes, I. J., and Senhauser, D. A. (1961). The role of auto-immunity in thyroid pathology. I. Colloquio Europeo de Endocrinologia, 217-230.

Dorff, G. B. (1934). Sporadic cretinism in one of twins. American fournal of Diseases of Children, 48, 1316-1325.

Faxen, N. (1935). Hypothyroidism in one of twins (1935). Acte⿳亠丷厂 paediatrica, 17, 565-573.

Federman, D., Robbins, J., and Rall, J. E. (1958). Some observations on cretinism and its treatment. Nerw England fournal of Medicine, 259, 610-615.

Fraser, G. R. (1964). Genetical Aspects of Thyroid Disease. In The Thyroid Gland, Vol. 2, pp. 271-297. Ed. by R. Pitt-Rivers and W. R. Trotter. Butterworths, London.

Fraser, G. R. (1969). The genetics of thyroid disease. Progress in Medical Genetics, 6, 89-115.

Frierson, H. F., Hawk, J. C., Jr., and Jenkins, M. Q. (1957). Sporadic cretinism with goiter occurring in identical twins. Fournal of Pediatrics, 51, 704-708.

Grebe, H. (1952). Diskordanzursachen bei erbgleichen $Z$ willingen. Acta Geneticae Medicae et Gemellalogiae, 1, 89-102.

Greig, W. R., Henderson, A. S., Boyle, J. A., McGirr, E. M., and Hutchison, J. H. (1966). Thyroid dysgenesis in two pairs of monozygotic twins and in a mother and child. Fournal of Clinical Endocrinology and Metabolism, 26, 1309-1316.

Gribetz, D., Talbot, N. B., and Crawford, J. D. (1954). Goiter due to lymphocytic thyroiditis (Hashimoto's struma). Its occurrence in preadolescent and adolescent girls. Nero England fournal of Medicine, 250, 555-557.

Hall, R., Owen, S. G., and Smart, G. A. (1960). Evidence for genetic predisposition to formation of thyroid autoantibodies. Lancet, 2, 187-188.

Harnack, G. A. von (1953). Eineiige Zwillinge mit diskordanter Hypothyreose. Archiv für Kinderheilkunde, 146, 60-63.

Hassan, T. H. A., Greig, W. R., Boyle, J. A., Boyle, I. T., and Wallace, T. J. (1966). Toxic diffuse goitre in monozygotic twins. Lancet, 2, 306-308.

Herrman, C. (1914). Sporadic cretinism-a clinical study of 41 cases. New York State fournal of Medicine, 14, 394-398.

Herrman, C. (1917). Three children with sporadic cretinism in one family. Archives of Pediatrics, 34, 831-836.

Hosen, H. (1940). Thyroid deficiency in twins. Fournal of Pediatrics, 16, 210-214.

Irvine, W. J., Macgregor, A. G., Stuart, A. E., and Hall, G. H. 
(1961). Hashimoto's disease in uniovular twins. Lancet, 2, 850853.

Jayson, M. I. V., Doniach, D., Benhamou-Glynn, N., Roitt, I. M., and El Kabir, D. J. (1967). Thyrotoxicosis and Hashimoto goitre in a pair of monozygotic twins with serum long-acting thyroid stimulator. Lancet, 2, 15-18.

Koplik, H. (1897). Sporadic cretinism and its distinction from forms of idiocy and other diseases. New York Medical fournal, 66, 309-317.

Levitt, T. (1954). The Thyroid. Livingstone, Edinburgh.

Lewit, S. G., Rywkin, I. A., Slrejsky, M. J., Fogelson, L. J., Dorfmann, I. A., and Lichzieher, I. B. (1930). Ueber die Genetik der Basedow'schen Krankheit und der ihr nahestehenden pathologischen Formen. Mediko-Biologicheskih Zhurnal, 6, 389.

Lowenstein, J. M. (1961). Hyperthyroidism in identical twins. Report of cases, one treated by surgery, the other by $1^{131}$. fournal of American Medical Association, 176, 377-378.

Lowrey, G. H., Aster, R. H., Carr, E. A., Ramon, G., Beierwaltes, W. H., and Spafford, N. R. (1958). Early diagnostic criteria of congenital hypothyroidism. A comprehensive study of fortynine cretins. American fournal of Diseases in Children, 96, 131143.

McCormack, K. R. and Sheline, G. E. (1961). Hyperthyroidism in young female twins. Acta genetical medicae et gemellologiae, 10 70-79.

Martin, L. and Fisher, R. A. (1945). The hereditary and familial aspects of exophthalmic goitre and nodular goitre. Quarterly fournal of Medicine, 14, 207-219.

Martin, L. and Fisher, R. A. (1951). The hereditary and familial aspects of toxic nodular goitre (secondary thyrotoxicosis). Quarterly fournal of Medicine, 20, 293-297.

Nabney, J. B. C. (1954). Multiple cretinism in a family. Lancet, 2, 1107.
Neel, J. V., Carr, E. A., Beierwaltes, W. H., and Davidson, R. T. (1961). Genetic studies on the congenitally hypothyroid. Pediatrics, 27, 269-285.

Neff, F. C. (1932). Exophthalmic goiter in identical twin girls. fournal of Pediatrics, 1, 239-243.

Osler, W. (1897). Sporadic cretinism in America. Transactions of the Congress of American Physicians and Surgeons, 4, 169-206.

Pickering, D. E. and Koulischer, N. (1956). Discordance of cretinism in monozygotic twins. American fournal of Diseases in Children, 92, 63-65.

Robinson, D. W. and Orr, T. G. (1955). Carcinoma of the thyroid and other diseases of the thyroid in identical twins. Archives of Surgery, 70, 923-928.

Shepard, T. H. II and Gartler, S. M. (1960). Increased incidence of nontasters of phenylthiocarbamide among congenital athyreotic cretins. Science, 131, 929.

Sill, E. M. (1905). Sporadic cretinism. Observations based on sixteen personal cases. Medical Neros, 86, 833-838.

Smeby, B. (1953). Medfødt hypothyreose hos to søsken. Nordisk Medicin, 50, 1304-1305.

Smith, S. M. and Penrose, L. S. (1955). Monozygotic and dizygotic twin diagnosis. Annals of Human Genetics, 19, 273-289.

Strickland, A. L. and Bass, J. W. (1969). Nongoitrous cretinism in monozygotic twins. American fournal of Diseases in Children, 118 927-931.

Warkany, J. and Selkirk, T. K. (1955). Discordant monozygotic twins. Hypothyroidism. American fournal of Diseases in Children, 89, 144-148.

Zaino, E. C. and Guerra, W. (1964). Hashimoto's disease (struma lymphomatosa) in identical twins. Archives of Internal Medicine, $113,70-71$. 